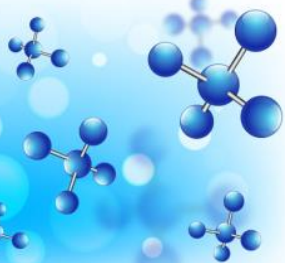

Article

\title{
Effect of Duration and Temperatur Breastmilk Storage and The way of Diluting Breastmilk on Protein and Fat Levels in Breastmilk
}

\author{
Mandria Yundelfa ${ }^{l}$, Mayetti $^{2}$, Nur Indrawaty Lipoeto ${ }^{3}$ \\ ${ }^{1}$ Study Program of Midwifery Masters Program, Faculty of Medicine, Andalas University, Padang \\ ${ }^{2}$ Children of the Faculty of Medicine Andalas University, Padang \\ ${ }^{3}$ Nutrition Sciences Faculty of Medicine at Andalas University, Padang,
}

SUBMISSION TRACK

Recieved: 15 Juni 2018

Final Revision: 23 Juni 2018

Available Online: 30 Juni 2018

\section{KEYWORDS}

Write, no more, than, five

CORRESPONDENCE

Phone: 081374619874

E-mail: mandria_bdr@yahoo.com

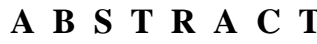

Exclusive breastfeeding is the best method of nutrition for infant to grow and develop. Changes in social often make women become to work increased from $50.77 \%$ (2016) to $50.89 \%$ (2017), so they think there is no time to give exclusive breastfeeding to her baby. But with the storage of breast milk, the baby will still get breast milk when the mother is at work. This study aims to determine the effect of duration and temperature of breastmilk as well as how to dilute frozen milk to protein and fat levels. The design of this study was one group pretest-posttest design with the pre experimental study. The data were analyzed by using $\mathrm{T}$ dependent test. The sample of this study is breast milk obtained from 5 breastfeeding mothers in the work area of LubukBuaya Public Health and Laboratory Animal Biotechnology of Andalas University in July in 2017 to May in 2018.There was significant decrease mean of protein and fat content in breastmilk during 5 days storage at refrigerator that mean of protein content $0,50 \pm 0,44 \mathrm{~g} / \mathrm{dL}$ and fat content $2,57 \pm 0,45 \mathrm{~g} / \mathrm{dL}$ statistically $(\mathrm{p}<0,05)$. There was no significant decrease in the mean of protein and fat content in breast milk, which was dissolved in refrigerator and warm water is average protein content $0.89 \pm 0.46 \mathrm{~g} / \mathrm{dL}$ and mean fat content $3.21 \pm 0.19 \mathrm{~g} / \mathrm{dL}$, direct melted breastmilk with mean of protein content is $0.91 \pm 0.52 \mathrm{~g} / \mathrm{dL}$ and mean of fat content is $3.05 \pm 0.25 \mathrm{~g} / \mathrm{dL}$ statistically ( $>0.05)$. The conclusion, there is no effect of protein and fat content in breast milk storaged for 4 hours in the room temperature, 14 days in freezer $(-15 \mathrm{C}), 28$ days in freezer $(-18 \mathrm{C})$ and how to dilute frozen milk. But there is adecrease on the levels of protein and fat in breast milk in 5-day storage in the refrigerator. 


\section{INTRODUCTION}

Exclusive breastfeeding is the best method of nutrition in infants for growth and development, both in the short and long term. ${ }^{1}$ Breast milk contains all the nutrients needed to build and provide energy for the growth and development of the baby optimal. The World Health Organization

(WHO) recommends that infants should be breastfed for at least 6 months. ${ }^{2}$

Based on PP no.33 of 2012 that every mother who gave birth should give exclusive breastfeeding to her baby. Regulation of the minister of health RI no. 15 th 2013 that every agency must support exclusivebreastfeeding programs by providing a special room for milking $\mathrm{ASI}^{3}$

However, in fact in the community one of them is the change of social order that makes many women who work outside the home, after giving birth, after giving birth they only get leave for 3 months, so they assume there is no time to give exclusive breastfeeding to her baby. ${ }^{4}$ In Indonesia , the number of female labor force in 2011-2015 averaged $50 \%$, increased in 2016 to $50.77 \%$ and in 2017 to $50.89 \%$, ie $73 \%$ of them are mothers who breastfeed and have children $<2$ years, while in West Sumatra in 2015 there are $55.73 \%$ and in 2016 to $59.49 \%$ female labor. Results Riskesdas 2013 states more than half of mothers who work breastfeeding her baby. ${ }^{3}$

Some of the factors that hinder the success of exclusive breastfeeding mothers in working mothers are short time offs, lack of workplace support, short time during work (not enough time to milk), and no room to milk. To address this delema, mothers can store breast milk that has been milked beforehand to be given to infants when the mother is absent from home or at work. 4 In addition, storage is needed when planning to delay feeding. ${ }^{5}$ Breastmilk storage is an innovation that needs to be developed and further investigated to find appropriate storage methods to minimize the loss of nutrients contained in breast milk and the future into a solution for the problems of mothers who can not breast feed their babies directly.

Breastfeeding mothers really need to pay attention to breastfeeding instructions. This is because breast milk contains many nutrients, anti-bacterial and anti-virus. The recommended length of storage is given at room temperature $\leq 25^{\circ} \mathrm{C}$ for $6-8$ hours, room temperature> $25^{\circ} \mathrm{C}$ hold $2-4$ hours, inside cooling bag at $15^{\circ} \mathrm{C}$ for 24 hours, in refrigerator $4^{\circ} \mathrm{C}$ to 5 days, stored in freezer $15^{\circ} \mathrm{C}$ for 2 weeks, freezer $-18^{\circ} \mathrm{C}$ for $3-6$ months. Refrigeration storage processes are beneficial for maintaining breast milk quality, but unacceptably long storage times will also affect breast milk quality. Aside from breastfeeding guidelines, it is important to note how to thaw free milk. ${ }^{6}$

Breastmilk storage performed by the mother during work which is then given to her baby is sometimes less than optimal. Optimal storage conditions are needed because breast milk is a product / food of human beings in this case categorized as mammals. Vegetable foods are relatively more durable when they are stored from animals. ${ }^{7}$ This means that breastmilk as a mammal product is relatively short in storage time, so breast milk storage needs optimal conditions and the most appropriate method of various storage methods available.

The storage process in the refrigerator is useful to maintain the quality of breast milk, but the content of protein and fat in breast milk is influenced by temperature and storage time. and how to melt. ${ }^{8}$ The 3 -day storage period is significantly related to changes in breast milk, this is thought to be due to bacterial activity lipolytics that produce lipase enzymes in breast milk. The lipolytic bacterium itself is a bacterium that requires minimal fat concentration for its growth and this group of bacteria produces lipase enzyme. ${ }^{7}$ The content of breast milk protein may decrease due to long storage. Decrease in protein levels occurs because 
during the process of denaturation, lactic acid bacteria actively perform the process of proteolysis and lipolysis to become substances that can be exploited by bacteria such as energy. By the time this mechanism takes place it will produce water so automatically the protein concentration will decrease

From a preliminary survey conducted by a researcher at one of the universities in Padang City, it was found that from 6 breastfeeding mothers, $83 \%$ still gave exclusive breastfeeding by extorting milk during college, $40 \%$ of them kept breastmilk for 1-2 months (due to distance ). And a survey conducted on the community Sei. Sapih Padang from 9 mothers working outside the home who have babies <6 months, found that $22 \%$ have given formula milk since actively working again, while $78 \%$ still breastfeed by milking and store it in refrigerator, got $14 \%$ milking with milk hand, $57 \%$ flushed with electric pump and $28 \%$ flushed with manual pump, while for milk storage, obtained $29 \%$ which store in refrigerator which have 1 door and $71 \%$ which have 2 door, where the storage container is got $86 \%$ using special plastic for breast milk storage and 14\% use glass bottles with rubber cover, for long and storage temperatures vary greatly according to maternal and infant activity, whereas for the average melting way they include breast milk in a storage container to warm water freshly prepared to boil.

Based on the above, the researchers are interested to conduct research on the effect of long and storage temperature of breast milk and how to melt frozen milk on protein and fat levels.

The results of this study are expected to provide benefits for mothers who work outside the home or housewives who have businesses outside the home, but still want to exclusively breastfeed to their babies by storing milk at the correct storage temperature and optimal so as to maintain the quality of breast milk good.

\section{METHODS}

This study aims to determine the effect of long and storage temperature of breast milk as well as how to dilute frozen milk to protein and fat levels. This research was conducted in the working area of Lubuk Buaya Public of Health and at Laboratory Animal Biotechnology of Andalas University from July 2017 to May 2018. This research is apre experimental design study with one group pretest-posttest design. Data were analyzed using t-dependent test (paired $t$ test) with significance level used $p$ $<0,05$. The aim of this research is to know the effect of milk storage duration and temperature and how to dilute frozen milk to protein and fat content by refinery, tip of micro pipette, sterile spoon, petroleum benzene, selenium, $\mathrm{H} 2 \mathrm{SO} 4$, Aquades.

Inclusion criteria: Mothers who are willing to be respondents, Mother is in good health, Mother with a history of pregnancy with gestational age> $37 \mathrm{mg}$, breast milk obtained from mothers who have babies aged 2 weeks to 20 weeks, Distance of pregnancy $\geq 2$ years, Mother with high school education equals, mother with lower socioeconomic level. Exclusion Criteria: I was not at the place when data collection was done, I did not agree to be taken to the UNAND Biotechnology Animal Laboratory, Mother did not consume drugs and alcohol and cigarettes Mother canceled the agreement to become a sample because of illness or other things.

The sampling technique in this study was a simple random sampling method to obtain 5 samples of 667 babies who were exclusively breastfed in the work area of the Lubuk Buaya Health Center in Padang City.

The mother who fulfilled the research requirements was taken as a research subject and was taken to the Animal Husbandry Faculty Animal Husbandry Biotechnology Laboratory, UNAND, then given an explanation before the approval of the research to be conducted. The researcher explained how to milk ASI using an electric ASI pump. Then the mother started milking milk accompanied by the researcher, the 
equipment used to milk the milk was prepared by a previously sterilized researcher. ASI needed in this study is \pm 70 $\mathrm{ml}$, which will be divided into 14 ASI bags with each containing $5 \mathrm{ml}$ of ASI, and each bag is given a code according to the sample. Furthermore, 2 breast milk bags from each sample as control were measured for protein and fat content as a comparison with ASI stored according to treatment (P1, P2, P3A, P3B, P4A, P4B).

Protein levels were measured using the Kjedhal method according to Sudarmadji, Haryono, and Suhardi (1996). The way it works is as follows: Destruction, the dried breast milk samples were taken as much as 1 gram, and put into the kjedhal flask and added 1 gram of selenium and $25 \mathrm{ml}$ of concentrated $\mathrm{H} 2 \mathrm{SO} 4$. Then it is reconstructed in an acid cupboard starting with low heat and shaking it at any time until the solution is clear yellow. Distillation, the solution is transferred to a distillation flask. Then added with aquades and $\mathrm{NaOH}$, then the solution is heated to all $\mathrm{N}$ of the liquid present in captured by $\mathrm{H} 2 \mathrm{SO} 4$ which has been added with 5 drops of Methyl Red indicator. Titration, the Erlenmeyer flask containing the extraction was titrated with $0.1 \mathrm{~N}$. NaOH for $25 \mathrm{ml}$ Erlenmeyer $0.05 \mathrm{~N}$ $\mathrm{H} 2 \mathrm{SO} 4,5$ drops of Methyl Red indicator, then titrated with $\mathrm{NaOH}$ until the color changes from red to clear yellow.

Fat content was determined based on the guidelines of Qanas and Zuki (1981), namely the sample weighed as much as 1 gram (X grams). Then wrapped in fat paper. Then dried in an electric oven for 12 hours at a temperature of $105-110^{\circ} \mathrm{C}$. The package is weighed hot one by one (Y) grams. Then extracted with benzema for 16 hours until the clear sochlet. Extraction was stopped and the sample was aired to dry (benzema evaporated). Then dried in an electric oven at a temperature of $105-110^{\circ} \mathrm{C}$ for 4 hours. The package is weighed heat one by one until the weight remains ( $\mathrm{Z}$ grams).

Numerical data obtained from the results of the study were tested for normality using the Shapiro-Wilk test (sample <50), obtained normal data distribution ( $p>0.05)$.

Bivariate analysis to examine the relationship between independent variables and dependent variables. The scale of measurement of variables in this study is numeric-numeric namely the influence of protein content on the duration and storage temperature of breast milk; fat content to the duration and temperature of ASI storage; protein content on how to dilute ASI; fat content on how to dilute breast milk, then used statistical test $\mathrm{t}$-dependent test ( $\mathrm{t}$ paired test). The significance level used was 0.05 with a $95 \%$ confidence level. Decisions from the results of statistical tests use $p$ value.

\section{RESULT}

The sample of this study is breast milk obtained from 5 breastfeeding mothers in the Work Area of LubukBuaya Health Center and UNAND Ranch Animal Biotechnology Laboratory in July 2017 until May 2018.

\begin{tabular}{ccc}
$\begin{array}{l}\text { Table 3.1 Effect of Old and Breastfeeding Storage } \\
\text { Temperature on Protein Levels }\end{array}$ & p \\
\hline $\begin{array}{c}\text { Old \& Temporary } \\
\text { Storage of Breast } \\
\text { Milk }\end{array}$ & $\begin{array}{c}\text { Protein levels } \\
\text { Average } \pm \text { SD } \\
\text { (gr/dL) }\end{array}$ & \\
\hline K & $1,15 \pm 0,65$ & 0,649 \\
P1 & $1,12 \pm 0,44$ & \\
\hline K & $1,15 \pm 0,65$ & 0,036 \\
P2 & $0,50 \pm 0,44$ & \\
\hline K & $1,15 \pm 0,65$ & 0,581 \\
P3A & $0,89 \pm 0,46$ & \\
\hline K & $1,15 \pm 0,65$ & 0,504 \\
P3B & $0,91 \pm 0,52$ & \\
\hline K & $1,15 \pm 0,65$ & 0,813 \\
P4A & $1,12 \pm 0,27$ & 0,946 \\
\hline K & $1,15 \pm 0,65$ & \\
P4B & $1,13 \pm 0,24$ & \\
\hline
\end{tabular}

The results showed the average protein content after 5 days storage at $4{ }^{\circ} \mathrm{C}$ decreased. Statistically showed no significant effect on fresh milk protein content with breast milk stored for 5 days at $4{ }^{\circ} \mathrm{C}$, this is indicated by $\mathrm{p}$ value $<0.05$. 
Table 3.2 Effect of Old and Breastfeeding Storage Temperature on Fat Levels

\begin{tabular}{ccc}
$\begin{array}{c}\text { Old \& Temporary } \\
\text { Storage of Breast } \\
\text { Milk }\end{array}$ & $\begin{array}{c}\text { Fat levels } \\
\text { Average } \pm \text { SD } \\
\text { (gr/dL) }\end{array}$ & p \\
\hline K & $3,27 \pm 0,16$ & 0,086 \\
P1 & $3,23 \pm 0,18$ & \\
\hline K & $3,27 \pm 0,16$ & 0,008 \\
P2 & $2,57 \pm 0,45$ & \\
\hline K & $3,27 \pm 0,16$ & 0,059 \\
P3A & $3,21 \pm 0,19$ & \\
\hline K & $3,27 \pm 0,16$ & 0,055 \\
P3B & $3,05 \pm 0,25$ & \\
\hline K & $3,27 \pm 0,16$ & 0,071 \\
P4A & $3,21 \pm 0,19$ & \\
\hline K & $3,27 \pm 0,16$ & 0,106 \\
P4B & $3,07 \pm 0,27$ & \\
\hline
\end{tabular}

The results showed that average fat content after 5 days storage at $4^{\circ} \mathrm{C}$ decreased. Statistically, there was a significant difference in the level of fresh milk fat with breast milk stored for 5 days at $4^{\circ} \mathrm{C}$, this is indicated by a value of $\mathrm{p}<0.05$.

Table 3.3 Effect of How to Liquidate Frozen Milk on Protein Levels

\begin{tabular}{ccc}
\hline $\begin{array}{c}\text { How to Melt Frozer } \\
\text { Milk }\end{array}$ & $\begin{array}{c}\text { Protein levels } \\
\text { Average } \pm \text { SD } \\
\text { (gr/dL) }\end{array}$ & p \\
\hline K & $1,15 \pm 0,65$ & 0,581 \\
P3A & $0,89 \pm 0,46$ & \\
\hline K & $1,15 \pm 0,65$ & 0,504 \\
P3B & $0,91 \pm 0,52$ & \\
\hline K & $1,15 \pm 0,65$ & 0,813 \\
P4A & $1,12 \pm 0,27$ & \\
\hline K & $1,15 \pm 0,65$ & \\
& & 0,946 \\
P4B & $1,13 \pm 0,24$ & \\
\hline
\end{tabular}

The results of this study showed a decrease in the mean protein content in breast milk that was liquefied in the refrigerator $\left(4^{\circ} \mathrm{C}\right)$ overnight before being used then with warm water at $37^{\circ} \mathrm{C}$ ie 0.26 and a decrease in the mean protein content in breastmilk directly into hot water with a temperature of $63^{\circ} \mathrm{C}$ is 0.25 . However, statistically showed no significant effect on protein content, it is indicated by $\mathrm{p}>0,05$.

Table 3.4 Effect of How to Liquidate Frozen Milk on Fat Levels

\begin{tabular}{ccc}
\hline $\begin{array}{c}\text { How to Melt } \\
\text { Frozen Milk }\end{array}$ & $\begin{array}{c}\text { Protein levels } \\
\text { Average } \pm \text { SD } \\
\text { (gr/dL) }\end{array}$ & p \\
\hline K & $3,27 \pm 0,16$ & 0,059 \\
P3A & $3,21 \pm 0,19$ & \\
\hline K & $3,27 \pm 0,16$ & 0,055 \\
P3B & $3,05 \pm 0,25$ & \\
\hline K & $3,27 \pm 0,16$ & 0,071 \\
P4A & $3,21 \pm 0,19$ & \\
\hline K & $3,27 \pm 0,16$ & 0,106 \\
& $3,07 \pm 0,27$ & \\
\hline
\end{tabular}

The results showed a decrease in the mean fat content in breast milk that was liquefied in refrigerator $\left(4^{\circ} \mathrm{C}\right)$ overnight before use and then with warm water temperature $37{ }^{\circ} \mathrm{C}$ that is 0,06 and decreased mean of fat content in breast milk which was melted directly on hot water with temperature $63{ }^{\circ} \mathrm{C}$ is 0.22 . However, statistically showed no significant effect on fat content, it is marked with $\mathrm{p}>0,05$.

\section{DISCUSSION}

Influence of Old and Storage Temperature of Breast Milk to Protein Level

The results showed the average protein content after 5 days storage at $4{ }^{\circ} \mathrm{C}$ decreased. Statistically showed no significant effect on fresh milk protein content with breast milk stored for 5 days at $4{ }^{\circ} \mathrm{C}$, this is indicated by $p$ value $<0.05$.

Protein content of breast milk can be decreased due to storage period and storage temperature. Decrease in protein levels is 
due to the process of denaturation, lactic acid bacteria actively perform the process of proteolysis and lipolysis to become substances that can be exploited by the energy-like bacteria. In this process occurs, usually will produce water so that automatic protein concentration will decline. ${ }^{9}$ Changes in milk protein levels during storage in the refrigerator due to the occurrence of protein denaturation caused one of the causes is acid. The longer the storage time, the higher the acidity of milk, this is due to the presence of lacic acid laceration bacteria such as streptococcus thermophilus, lactobacillus lactis and lactobacillus thermophillus, which causes increased lactic acid in milk. ${ }^{10}$

Denaturation is defined as changes in secondary, tertiary and quartz structures of protein molecules without breaking the peptide bond. In this denaturation process, the protein will undergo changes in its physical properties and biological activity. ${ }^{11}$ The secondary, tertiary and quartz structures of the protein molecule may change in denaturation but the peptide bond is intact because of its very stable properties. ${ }^{9}$ Peptide bonds show the biological properties of a protein . The existing theory explains that nutritional value will not change even if the protein loses its biological properties. ${ }^{12}$

Long-term effects of breast milk storage on protein and fat content contained in breast milk with 32 samples stored in refrigerators for 0 hours (control), 24 hours, 48 hours and 72 hours. There was significant difference of mean protein content based on storage time with $\mathrm{p}<0,05.4$ Effect of temperature variation and length of storage on nutritional quality of mother's milk with 21 samples found that storage time has a significant influence on the change of milk protein level. $^{7}$

\section{Influence of Old and Breastfeeding Storage Temperature to Fat Level}

The results showed that average fat content after 5 days storage at $4{ }^{\circ} \mathrm{C}$ decreased. Statistically, there was a significant difference in the level of fresh milk fat with breast milk stored for 5 days at $4^{\circ} \mathrm{C}$, this is indicated by a value of $\mathrm{p}<0.05$.

The effects of the inhibition process on the growth activity of pathogenic bacteria in breast milk began to decrease after being stored for 72 hours. Tests performed on staphylococcus aureus resulted in lower organism CFU results than before storage. ${ }^{13}$ During storage, breast milk may have lipolysis, a process of hydrolysis of fatty ester bonds (tryacylglycerols) resulting in free fatty acids and glycerol. ${ }^{12}$ Lipase enzymes resulting from metabolism of lactic acid bacteria (BAL) and naturally occurring in breast milk and its lipolytic properties hydrolyze the fat, in which the lipase is derived from microbes or naturally present in breast milk.

Breastfeeding for 3 days was significantly associated with changes in breastfeeding, presumably due to lipolytic lipid activity. ${ }^{7}$ Lipolsis proceeded very rapidly from the first hour of storage and the process reached $8 \%$ at 24 hours of storage. ${ }^{14}$

The results of this study indicate that storage temperature and storage time have an effect on protein content in breast milk. Although some essential nutrients and components will change during storage, there is at least a good approach in handling temperature and time-related storage so that they remain safe for babies to consume and still contain optimal nutritional value. Based on the results of this study it can be recommended that for breastmilk storage preferably at freezer temperature $\left(-15^{\circ} \mathrm{C}\right)$ for 14 days and freezer $\left(-18^{\circ} \mathrm{C}\right)$ for 28 days.

\section{Effect of How to Liquidate Frozen Milk on Protein Content}

The results of this study showed a decrease in the mean protein content in breast milk that was liquefied in the refrigerator $\left(4^{\circ} \mathrm{C}\right)$ overnight before being used then with warm water at $37^{\circ} \mathrm{C}$ ie 0.26 and a decrease in the mean protein content in breastmilk directly into hot water with a temperature of $63^{\circ} \mathrm{C}$ is 0.25 . However, statistically showed no significant effect on protein content, it is indicated by $\mathrm{p}>0,05$. 
The results showed that the average decrease in protein content in breast milk that was liquefied in the refrigerator $\left(4^{\circ} \mathrm{C}\right)$ overnight before use then with warm water was $37^{\circ} \mathrm{C}$ lower than the average decrease in protein content in breast milk that was liquefied directly to hot water at $63{ }^{\circ} \mathrm{C}$. There was no significant difference in fat, protein, lactoferrin and secretory immunoglobulin between breastfeeding methods, heating of liquid milk and the maintenance of warm milk at liquid temperatures. ${ }^{15}$

Warming up the physiological temperature significantly affects the nutritional and immune properties of breast milk. The Breastfeeding Protocol recommends the disbursement of frozen milk by placing it in the refrigerator the night before using or gently rewarm by placing the container under warm water or in a warm water bowl, ${ }^{16}$ otherwise the frozen milk should be liquefied quickly, usually by holding the container over warm water hot). Breast milk is often heated in electric-based bottle warmers that can exceed $80^{\circ} \mathrm{C}$, the temperature at which many beneficial properties of breast milk will be lost. ${ }^{8}$

In this study, the temperatures used to melt frozen milk were temperatures of $4{ }^{\circ} \mathrm{C}$ then $37^{\circ} \mathrm{C}$ and $63{ }^{\circ} \mathrm{C}$, so that the average protein content in the liquefaction process was reduced but not significant, meaning that the melting of frozen milk at temperatures above $80^{\circ} \mathrm{C}$ will affect the decrease in protein levels in breast milk. Although some nutrients and essential components will change during disbursement of frozen milk, there is at least a good approach in handling the melting of frozen milk related to how to dilute to keep the milk safe for babies to consume and still contain optimal nutritional value. Based on the results of this study it can be recommended that to dilute the frozen milk can be done by placing it in the refrigerator overnight before using then with warm water temperature $37^{\circ} \mathrm{C}$.

\section{Effect of How to Liquidate Frozen Milk on Protein Content}

The results showed a decrease in the mean fat content in breast milk that was liquefied in refrigerator $\left(4^{\circ} \mathrm{C}\right)$ overnight before use and then with warm water temperature $37^{\circ} \mathrm{C}$ that is 0,06 and decreased mean of fat content in breast milk which was melted directly on hot water with temperature $63{ }^{\circ} \mathrm{C}$ is 0.22. However, statistically showed no significant effect on fat content, it is marked with $p>0,05$.

The results showed that the decrease in the mean fat content in breast milk that was liquefied in the refrigerator $\left(4^{\circ} \mathrm{C}\right)$ overnight before being used then with warm water was $37^{\circ} \mathrm{C}$ lower than the decreased mean fat content in breastmilk which was liquefied directly at hot water at $63^{\circ} \mathrm{C}$. This is in line with a study conducted by Ballard et al that there was no difference in triglyceride concentration averaging 97\% lipid content between fresh milk $(2.64 \mathrm{~g} / 100 \mathrm{~mL})$ and milk stored at $-18{ }^{\circ} \mathrm{C}$ for 28 days and then thawed in the refrigerator $\left(4^{\circ} \mathrm{C}\right)$ with a lipid content of $2.60 \%$ / $100 \mathrm{~mL} .17$ There was no significant difference in fat, protein, lactoferrin and secretory immunoglobulin between breastfeeding methods, heating of liquid milk and the maintenance of warm milk at liquid temperature. ${ }^{15}$

Warming up the physiological temperature significantly affects the nutritional and immune properties of breast milk. ASI is often heated in an electric-based bottle warmer that can exceed $80^{\circ} \mathrm{C}$, a temperature in which many beneficial properties of breastmilk will be lost.18 High temperatures may induce a variation in fat profile compared with fresh milk. ${ }^{8}$ Breeding Protocols suggest thawing of frozen milk by placing it in a cupboard ice the night before using or gently rewarm by placing the container under warm water or in a warm water bowl, ${ }^{16}$ besides the frozen milk should be melted quickly, usually by holding the container over warm water (not hot) .2 In this study, the temperature used to dilute the frozen milk is $37^{\circ} \mathrm{C}$ and $63^{\circ} \mathrm{C}$, so the average fat content in the liquefaction 
process is decreasing but not significant, meaning that melting of the frozen milk at temperatures above $80^{\circ} \mathrm{C}$ will affect the decrease in fat content in breast milk. Although some essential nutrients and components will change during disbursement of frozen milk, there is at least a good approach in handling the melting of frozen milk related to how to dilute to keep the milk safe for babies to eat and still contain optimal nutritional value.

Based on the results of this study it can be recommended that to dilute the frozen milk can be done by placing it on the refrigerator $\left(4^{\circ} \mathrm{C}\right)$ overnight before use then with warm water temperature $37^{\circ} \mathrm{C}$.

This study has several limitations, namely breast milk and how to dilute frozen breast milk is limited to 4 hours of storage at room temperature $\left(25^{\circ} \mathrm{C}\right), 5$ days storage at the refrigerator $\left(4^{\circ} \mathrm{C}\right), 14$ days storage in the 1-door freezer $\left(-15^{\circ} \mathrm{C}\right)$ which is thawed by placing it in the refrigerator overnight before use and then soaked in warm water at $37^{\circ} \mathrm{C}$ for 5 minutes and 14 days in the 1 door freezer $\left(-15^{\circ} \mathrm{C}\right)$ which is thawed immediately with hot water $63^{\circ} \mathrm{C}$ for 5 minutes, storage 28 days in a 2 -door freezer $\left(-18{ }^{\circ} \mathrm{C}\right)$ thawed by placing it in the refrigerator overnight before using it then soaking it in warm water at $37^{\circ} \mathrm{C}$ for 5 minutes and 28 days in a 2 -door freezer (-18 $\left.{ }^{\circ} \mathrm{C}\right)$ which is immediately soaked with hot water $63^{\circ} \mathrm{C}$ for 5 minutes. To see the decrease in protein and fat levels in ASI stored and liquefied, the storage time and temperature should vary.

\section{CONCLUSION}

There was no decrease in protein and fat content in breast milk stored for 4 hours at room temperature, for 14 days and 28 days in the freezer, but there was a decrease in protein and fat in the milk stored for 5 days in the refrigerator. There is no decrease in protein and fat levels in frozen milk that is melted in the refrigerator and warm water and frozen milk that is liquefied directly in hot water.
Suggestion: For mothers who work, housewives who have business outside the house or mothers who cannot directly breastfeed their babies within a certain period, can still provide exclusive breastfeeding to their babies by milking and storing breast milk for 4 hours on room temperature and for a long time ASI must be stored at freezer temperature and storage is not recommended at the refrigerator. For mothers who have spent more than 4 hours traveling during their education, they can continue to provide exclusive breastfeeding, namely by milking ASI and delivering it using a cooler bag and placing it directly in the freezer so that it maintains the quality of breast milk properly. 


\section{REFERENCE}

Aumeistere L, Ciprovica I, Zavadska D, Celmalniece K. Lactose content of breast milk among lactating women in Latvia. 2017:169-73.

Comerford KB, Ayoob KT, Murray RD, Atkinson SA. The role of avocados in maternal diets during the periconceptional period, pregnancy, and lactation. Nutrients. 2016;8(5):313-33.

Dawodu A, Zalla L, Woo JG, Herbers PM, Davidson BS, Heubi JE Morrow AL. Heightened attention to supplementation is needed to improve the vitamin D status of breastfeeding mothers and infants when sunshine exposure is restricted. Maternal and Child Nutrition. 2014;10(3):383-97.

IDAI. Breast Milk and Breastfeeding. Recommendation IDAI. 2010;1-9 Handa D, Ahrabi AF, Codipilly CN, Shah S, Ruff S, Potak D, Schanler RJ. Do thawing and warming affect the integrity of human milk? Journal of Perinatology. 2014;34(11):863-66.

Iqbal M, Lestari LA, Kurdanti W, Mardiyati LN. Effect of temperature and storage duration on lactose, protein and fat content of breast milk. Jurnal Gizi Kita. 2016;11:50-5.

Jocson MAL, Edward OM, Richard DS. The effects of nutrient fortification and varying storage conditions on host defense properties of human human milk. Pediatrics. 2008;100:240-3.

Indonesian Ministry of Health. Situation and analysis of exclusive breastfeeding. Center for Data and Information Ministry of Health National of Indonesian. 2015:51(6):1-40.

Lorico J, Perez M, Makati ON. Bacterial growth-inhibiting activity of expressed human breast milk on common neonatal pathogens, staphylococcus aureus, escherichia coli and klebsiella. PIDSP Journal. 2013;13(1):2-7.

Lawrence RA, Lawrence RM. Breastfeeding: A guide for the medical profession, 8th edition, by Ruth A. Lawrence and Robert M. Lawrence. Acta Paediatrica, 2016;105(8):983-93.

Ballard O, Morrow AL. Human Milk Composition: Nutrients and Bioactive Factors. Pediatric Clin North Am. 2012;7(4):304-12.

Mustafa S, Abdul A, Mohmed A, Mohamed E, Ahmed S, Yas I, Ahmed A. Effect of storage temperature on the microbiological. 2013:14(1): 115-21.

March OP, March R. ABM Clinical Protocol 8: Human milk storage information for home use for full-term infants (original protocol march 2004; Revision \#1 March 2010). 2010;5(3):27-31.

Ogechi UP, Irene II. Protein and amino acid composition of breast milk of mothers in Umuahia, Urban Nigeria. European Journal of Experimental Biology. 2013;3(3):605-8.

Sari IP, Yerizel E. The long-standing effect of storage of ation on protein and fat content contained in breast milk. Jurnal Kesehatan Andalas. 2014;5(1):56-9. 
Thatrimontrichai A, Janjindamai W, Puwanant M. Fat loss in thawed breast milk: Comparison between refrigerator and warm water. Indian Pediatrics. 2012;49(11):877-80.

Zabary SAV, Mimou FB. Human milk warming temperatures using a simulation of currently available storage and warming methods. Plos One. 2015;10(6):1-13.

\section{BIOGRAPHY}

First Author. The author won the Midwifery expert degree in 2009, then continued the education of Diploma IV educator midwives and graduated in 2014, then in 2015 the author continued his Midwifery Masters education and graduated in 2018. The author works at the Dharma Landbouw Padang STIKes from 2010 to the present.

Second Author. Dr. dr. Mayetti, SpA (K), IBCLC, she is Pediatrician Dr. M Djamil Padang Hospital, Head of Perinatology at IPDSA FK Unand / RS Dr M Djamil Padang, Head of PGD Sub Bag in IPDSA FK Unand / RS Dr M Djamil Padang, National Coach for Neonatal Resuscitation with the American Academy of Pediatric American Heart Association Standard, Lactation Consultant (IBCLC = International Board Certified Lactation Consultant), P2KP-P2KS PONED / PONEK Coach Team, Secretary of the High Risk Perinatal Working Group at Dr M Djamil Hospital, Padang, Chairman of the High Risk Perinatal Working Group of Dr M Djamil Hospital in Padang.

Third Author. Prof. Dr. Nur Indrawaty Lipoeto, MSc, Ph.D., SpGK, Professor of Nutritional Sciences at Andalas University, Padang, West Sumatra, Indonesia. Has obtained the award carried out his duties as Dean of Unand Public Health for 2012-2015. 